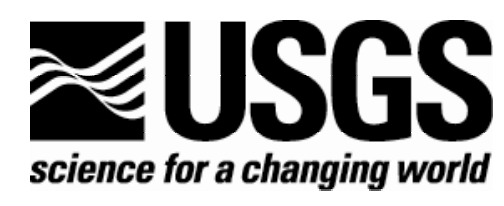

\title{
ANALYSES OF COAL FROM THE FERRON SANDSTONE MEMBER OF THE MANCOS SHALE NEAR EMERY, UTAH
}

By Charles E. Barker

Open-File Report 2004-1279

U.S. Department of the Interior

U.S. Geological Survey 


\section{Table of Contents}

Page

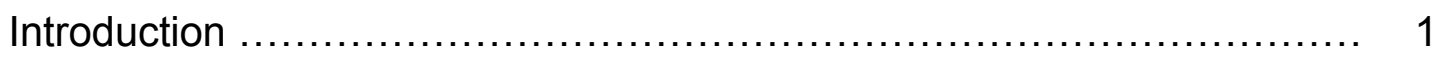

Acknowledgements .................................................... 3

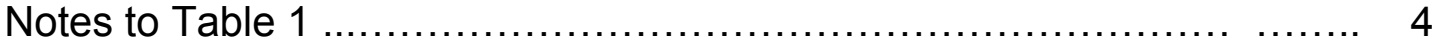

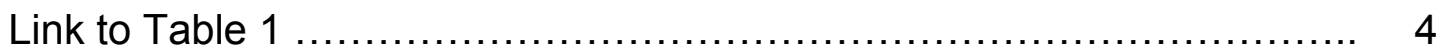

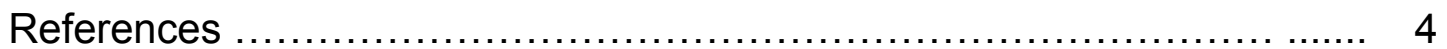




\section{Introduction}

As part of a study of the coal facies controls on coalbed methane properties across the informally named "Last Chance Delta" an Upper Cretaceous delta within the Ferron Sandstone Member of the Mancos Shale around Emery, Utah, the USGS sampled and arranged for chemical analysis of coal exposures (Table 1). The USGS samples from this study were analyzed under a contract with Geochemical Testing Division of the Energy Center (Somerset, Pennsylvania). Coal outcrops are emphasized in this study because weathering of the coals at the surface makes otherwise subtle and(or) obscure petrographic features that make up coal lithofacies visible in hand specimen. Weathered coals are otherwise poor candidates for coal quality studies because the coal chemistry may be altered in often unpredictable ways. However, comparison to mine run, drill core data from published coal analysis data in the area (Affolter et al.,1979; Bragg et al., 1998; Doelling, 1972; Keith, 1989; and Sommer et al., 1991) shows that the coal proximate data are affected mostly by changes in the forms of sulfur, as evidenced by the widespread yellowish pyrite weathering staining within the near-surface coals and detectable levels of the sulfate form of sulfur (Table 1). Virtually any content of sulfate is an indicator of a weathered coal.

This study was part of a larger effort that involved characterizing the Ferron coals in terms of their solid, pore water and gas geochemistry, hydrology, ultimate coal chemistry, coal adsorption isotherm, coal petrology and depositional environment, structural and burial history as well as production and engineering aspects (Collett and Barker, 2003). This area is well suited for a detailed study because the coal-bearing Ferron Sandstone Member crops out for tens of kilometers along depositional strike and also along the trough of the basin exposed along the eastern front of the Wasatch Plateau, Utah. In this setting, the Ferron Sandstone Member has a similar depositional, hydrologic, and thermal history but only produces commercial methane to the north of Emery-even where the coals are buried at similar depths near Emery. Thus, our outcrop and borehole study seeks to answer one question: Why, given the consistency of the geologic setting, do the Ferron coalbeds produce only commercial methane in the fields to the north of the Emery area? The apparent answer is the extensive and deep weathering of these coals caused by their exhumation of the water table and consequent long term exposure to air documented by the extensive pyrite weathering and the presence of sulfate sulfur (Table 1). The pervasive weathering is thought to have dulled the coals in the Emery Area--probably by an inertinization process. Adsorption isotherms indicate weathering to a dull coal would lead to a markedly reduced gas storage capacity as compared to bright coal (Figure 1). 


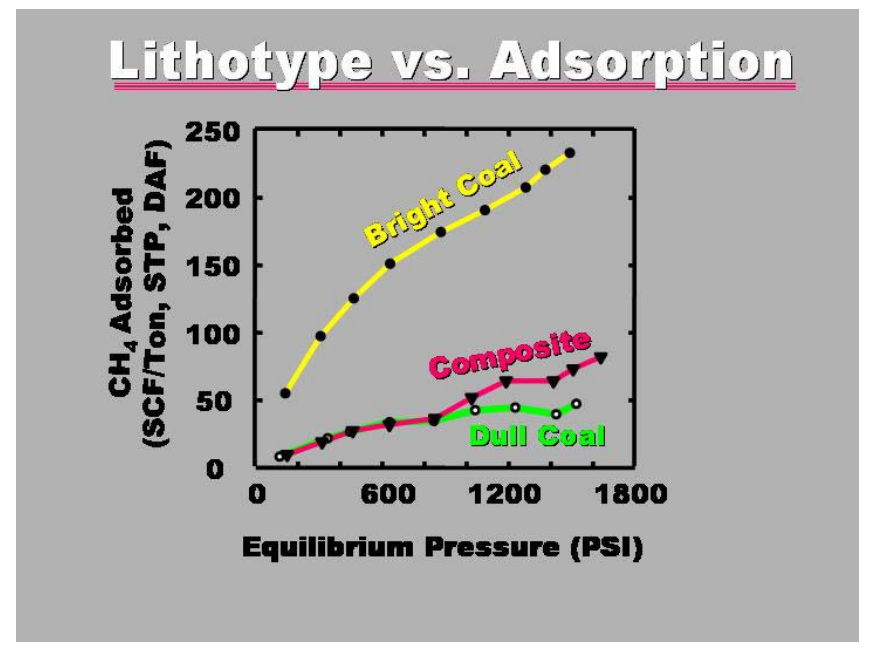

Figure 1. Comparison of Coal Lithotype versus Methane Adsorption Capacity in the Ferron A coal, exposed in the Interstate 70 road cut, near Emery, Utah.

The USGS samples for this study were gathered from exposed coal beds in outcrop and small open pit coal mines from 1996 to 1999. This Open File report is a compilation of the results of cooperative studies among Federal, State, gas production company geologists and private consultants and makes them available to the public at large.

The results of proximate, calorific value and, in some cases, forms of sulfur analyse of the USGS samples are presented in an Excel ${ }^{\circledR}$ based spreadsheet. The latitude and longitude data given in Table 1 were made using a Department of Defense precise GPS measurement at the sample locality.

The coal zone listed in Table 1 uses the nomenclature of Lupton (1916) for the Ferron Sandstone Member with the exception of the "sub A", a coal zone that crops out only in the Limestone Cliffs, Coal Cliffs and Dry Wash areas near Emery, Utah (Ryer, 1981). The coal zones listed in Table 1 were identified based on the mapping of T.C.V. van den Bergh (SGS Minerals Services, Huntington, Utah).

Note that, if required, conversion of the proximate data to dry, ash-free basis can be implemented using the raw data presented here and equations presented in ASTM (2001) or Ward (1984).

\section{Acknowledgements}

Brenda Pierce (USGS, Reston) taught me how to recognize coal subfacies and to sample coal plies that made this work possible. Sharon Swanson (USGS, Reston) shared her knowledge on the effects of volcanic ash on coal quality mire in the area and also helped with the coal sampling. T.C.V. van den Bergh (SGS Minerals Services, Huntington, Utah) shared her coal zone mapping and helped backpack out coal samples. James R. Garrison, Jr. (Colorado Plateau Field Institute, Price, Utah) also helped backpack out coal samples and provided the composite coal samples from Coyote Basin, and I-coal exposed along Interstate-70, that consists of the coal above and below the sandstone channel as described by Ryer and Langer (1980). Bob Lamarre (Texaco, Denver, Colorado) and Terry Burns (River Gas, Northport, Alabama) shared their knowledge of the northern portion of the Ferron coalbed methane play that helped shape the sampling plan. Creties Jenkins (ARCO, Dallas, Texas) contributed his 
helpful perspectives on coal facies and their controls on coalbed methane based on his studies of Chinese coal basins.

\section{Notes to Table 1.}

1. All of the samples listed are channel samples taken by digging down to hard coal and then trenching along the coal seam in a manner similar to the technique described by Thomas (1992; his Chapter 9). Each channel was sampled twice, in that we took separate ply samples as well as aggregating all the plies into a single composite sample of the entire coal seam. All partings, either as a single parting or, as the aggregated thickness of adjacent partings of different lithology, that are greater than or equal to $25 \mathrm{~cm}$ thick, were excluded from the composite samples.

2. Coal plies are defined by Thomas (1992) as physical subdivisions of a coal. Plies are herein used as physical units within a coal zone that have a distinctive megascopic appearance. Plies are roughly related to coal lithotypes on the microscopic level and as such constitute field-recognizable coal lithofacies units.

3. All analyses are reported on an as received basis.

4. Abbreviations used : Comp = composite; Crk = Ceek; n.a. = not analyzed or not reported; med = medium; pyw = pyrite weathering; $v=$ very; volc $=$ volcanic .

\section{Link to Table 1.}

table for USGS OF 4-04 barker data only v-3.xls

\section{References}

Affolter, R. H., J. R. Hatch, and T. A. Ryer, 1979, Chemical analyses of coal and shale from the Ferron Sandstone Member of the Mancos Shale, Emery coal field, Emery County, Utah: U.S. Geological Survey Open-File Report 79-858, 36 p.

American Society for Testing Materials (ASTM), 2001, Gaseous fuels, coal and coke: In Petroleum Products, Lubricants and Fossil Fuels: 2001 Annual Book of ASTM Standards: Vol. 05.06, p. 190-195.

Bragg, L.J., Oman, J.K., Tewalt, S.J., Oman, C.L., Rega, N.H., Washington, P.M., and Finkelman, R.B., 1998, U.S. Geological Survey coal quality (COALQUAL) database: version 2.0: U.S. Geological Survey Open-File Report 97-134. (CD-ROM).

Collett, T.S. and C.E. Barker, editors, 2003, Coalbed methane in the Ferron Coals, Utah: Special issue, International Journal of Coal Geology, v. 56, no. 1 and 2.

Doelling, H. H., 1972, Central Utah coal fields - Sevier-Sanpete, Wasatch Plateau, Book Cliffs, and Emery: Utah Geological and Mineral Survey Monograph Series, no. 3, 572 p.

Keith, A. C., 1989, Coal quality characteristics of Utah's coal beds in and near potentially producible coal tracts: Utah Geological and Mineral Survey Report of Investigation 219, $174 \mathrm{p}$. 
Lupton, C. T., 1916, Geology and coal resources of Castle Valley in Carbon, Emery, and Sevier Counties, Utah: U.S. Geological Survey Bulletin 628, 88 p.

Ryer, T. A., 1981, Deltaic coals of Ferron Sandstone Member of Mancos Shale predictive model for Cretaceous coal-bearing strata of Western Interior: AAPG Bulletin, v. 65 , no. 11 , p. $2323-2340$.

Ryer, T.A. and Anna W. Langer, 1980, Thickness change involved in the peat to coal transformation for a bituminous coal of Cretaceous age in Central Utah. Journal of Sedimentary Petrology, v. 50, p. 987-992.

Sommer, S. N., D. M. Bodily, and E. M. Whitney, 1991, Characteristics of Utah's coals in the University of Utah's coal sample bank: Utah Geological Survey Report of Investigation No. 226, 52 p.

Thomas, L., 1992, Handbook of Practical Coal Geology: John Wiley and Sons, New York, $338 \mathrm{p}$.

Ward, C.R., editor, 1984, Coal Geology and Coal Technology: Boston, Blackwell Scientific Publications, $345 \mathrm{p}$. 